\title{
Comparison of the titres of ASO, anti-DNase B, and antibodies against the group polysaccharide of group A streptococci in children with streptococcal infections
}

\author{
L. E. GOEDVOLK-DE GROOT, N. MICHEL-BENSINK, M. M. VAN ES-BOON, \\ A. H. VAN VONNO, AND M. F. MICHEL
}

From the Department of Clinical Microbiology, Medical Faculty, Erasmus University, Rotterdam, The Netherlands

SYNOPSIS Antibodies against the group polysaccharide of group A streptococci were estimated by means of a haemagglutination reaction. In this reaction human erythrocytes of blood group $\mathrm{O}$ were sensitized with polysaccharide esterified with myristoylchloride. The optimal conditions of the reactions were determined by varying the ester group content in the antigen and the amount of ester used for sensitization. The specificity of the reaction could be established by reacting sensitized erythrocytes with homologous and heterologous sera and by absorption experiments. Antistreptococcal group A polysaccharide titres (ASPAT) and antibody levels to streptolysine O and DNase-B were compared in a group of 52 children with proved streptococcal infection and in 52 age- and season-matched controls. Antibody levels were significantly higher in the patient group than in the controls. In the ASPAT there was clearly less overlap between patients and controls than in both other reactions. In the patient group the ASO titres were raised above normal in 27 cases $(51.9 \%)$, anti-DNase-B titres in $18(34.6 \%)$, and ASPAT in $40(76.9 \%)$. Taken together the three reactions gave a positive score in 51 cases $(98.1 \%)$ in the patient group against 17 cases $(32.7 \%)$ in the controls. A positive antibody response is usually defined as a rise of two dilution increments between the acute and convalescent sera. According to this definition the ASPAT showed a response in $42 \%$, ASO and/or DNase-B in $42 \%$, and the three reactions taken together in $68 \%$ of paired sera from patients. It is believed the ASPAT will prove a welcome addition to the diagnostic outfit when the presence of streptococcal infection in children is considered.

The demonstration of elevated titres of antibodies to one of the antigens of group A streptococci is a useful aid in the diagnosis of infection with these and in rare cases with related bacteria. Until recently attention was mainly directed to the estimation of antibodies against extracellular products of group A streptococci. Considerable information has been gathered about the significance of the values of ASO, anti-DNase B, and antihyaluronidase titres in relation to preceding streptococcal infections. It is conceivable that during infection antibodies are not only formed against extracellular but also against cellular products of the streptococcus. Antibodies to group A streptococcal polysaccharide (A-CHO) were shown to be present in human sera by Received for publication 13 August 1974.
Karakawa, Osterland, and Krause (1965), Schmidt and Moore (1965), Dudding and Ayoub (1968), Erwa, Maxted, and Brighton (1969), and Kaplan, Ferrieri, and Wannamaker (1974). A passive haemagglutination reaction for the detection of A-CHO antibodies was described by Goldstein and Caravanno (1967), Hämmerling and Westphal (1967), and Slade and Hämmerling (1968). In this reaction red cells sensitized with A-CHO esterified with stearoylchloride were used as the antigen. In the present study a similar reaction for the estimation of antistreptococcal polysaccharide A titres (ASPAT) is described. The ASPAT is compared with the values for ASO and anti-DNase B titres in a group of children with proved streptococcal infection of recent date. 


\section{Materials and Methods}

PREPARATION OF GROUP A POLYSACCHARIDE For the preparation of A-CHO freeze-dried group A streptococci of the $\mathrm{M}$-proteinless strain AJ/17/A4 were extracted with formamide according to Fuller (1938). The polysaccharide was purified as described by Michel and Krause (1967). The purity of the polysaccharide was checked with the quantitative precipitation reaction (McCarty and Lancefield, 1955). Only products with equivalence points in this reaction of $125 \mu \mathrm{g}$ antigen per $\mathrm{ml}$ or less were judged sufficiently pure to be used as antigen in the haemagglutination reaction.

\section{ESTERIFICATION OF POLYSACCHARIDE}

A-CHO was esterified according to the procedure described by Hämmerling and Westphal (1967) as modified by Pavlovskis and Slade (1969). Myristoylchloride (Koch and Light) was used instead of stearylchloride. Before use liquids were dried with molecular sieves (type 4, BDH) and A-CHO over $\mathrm{P}_{2} \mathrm{O}_{5}$ in vacuo. After esterification the product was dialysed against alcohol and water and freeze dried. From this product a stock solution containing 250 $\mu \mathrm{g} / \mathrm{ml}$ was prepared and kept at $-20^{\circ} \mathrm{C}$.

\section{SENSITIZATION OF ERYTHROCYTES}

Red cells were sensitized with esterified A-CHO according to the method described by Slade and Hämmerling (1967). Human citrated blood (blood group 0) of healthy blood bank donors was kept at $4^{\circ} \mathrm{C}$ for a maximum of five days. Before sensitization erythrocytes were washed three times in $0.85 \% \mathrm{NaCl}$. One $\mathrm{ml}$ of packed cells was suspended in $90 \mathrm{ml} 0.85 \%$ $\mathrm{NaCl}$. To this suspension $1 \mathrm{ml}$ of the stock solution of esterified A-CHO was added dropwise under manual agitation. The volume was then brought to $100 \mathrm{ml}$ with saline. The cell suspension was incubated for 30 minutes at $37^{\circ} \mathrm{C}$ and stabilized for one hour at $4^{\circ} \mathrm{C}$. Excess polysaccharide was removed by $\frac{0}{\vec{*}}$ repeated (three times) washing of the erythrocytes 은 in saline. The sensitized erythrocytes were finally $\vec{F}$ resuspended in $200 \mathrm{ml}$ saline, ie, $0.5 \%$ suspension.

\section{HAEMAGGLUTINATION TEST}

All sera were inactivated for 30 minutes at $56^{\circ} \mathrm{C}$. Rabbit sera were in addition absorbed with human erythrocytes for 30 minutes at $37^{\circ} \mathrm{C}$. Starting with an initial dilution of 1 in 4 twofold serial dilutions were made in plastic trays (Disposal Trays, Mod. 96-SC, Linbro Chem Inc, New Haven, Conn). Physiological saline containing $0.1 \%$ human albumin was used as diluent. To each serum dilution with a volume of $0.2 \mathrm{ml}$ an equal volume of sensitized erythrocytes was added. After mixing and incubation during one hour at $37^{\circ} \mathrm{C}$ the haemagglutination titres were read. The lowest dilution showing agglutination was considered the endpoint of the titration. Preceding each titration the quality of the sensitized erythrocytes was checked using three sera with known titres, ie, 4, 256, and 1024. Antistreptolysin titres were estimated according to Rantz and Randall (1945). Dnase-B was prepared according to the method of Marker and Gray (1972), and anti-Dnase-B titres were measured as described byKlein,'Baker, Addison and Moody (1969).

\section{Results}

In order to establish the optimal conditions of the ASPAT reaction a number of variables was investigated.

INFLUENCE OF INCREASING ESTERIFICATION AND OF AN INCREASING AMOUNT OF ESTERIFIED POLYSACCHARIDE ON THE TITRE VALUE Fifty mg amounts of A-CHO were esterified with $2 \cdot 5,5,7 \cdot 5$, and $10 \mathrm{mg}$ myristoylchloride respectively. The products of these esterifications were tested with

\begin{tabular}{|c|c|c|c|c|c|c|c|c|c|c|c|c|c|c|c|c|}
\hline \multirow{4}{*}{ Serum ${ }^{1}$} & \multicolumn{16}{|c|}{ Myristoylchloride per $50 \mathrm{mg} \mathrm{A}-\mathrm{CHO}$} \\
\hline & \multirow{2}{*}{\multicolumn{4}{|c|}{$\frac{2.5 \mathrm{mg}}{\operatorname{Ester}^{2}(\mu \mathrm{g})}$}} & \multirow{2}{*}{\multicolumn{4}{|c|}{$\frac{5 \mathrm{mg}}{\text { Ester }(\mu \mathrm{g})}$}} & \multirow{2}{*}{\multicolumn{4}{|c|}{$\frac{7.5 \mathrm{mg}}{\text { Ester }(\mu \mathrm{g})}$}} & \multirow{2}{*}{\multicolumn{4}{|c|}{$\frac{10 \mathrm{mg}}{\text { Ester }(\mu \mathrm{g})}$}} \\
\hline & & & & & & & & & & & & & & & & \\
\hline & $2 \cdot 5$ & 5 & 10 & 20 & $2 \cdot 5$ & 5 & 10 & 20 & $2 \cdot 5$ & 5 & 10 & 20 & $2 \cdot 5$ & 5 & 10 & 20 \\
\hline $\begin{array}{l}1 \\
2 \\
3 \\
4 \\
5 \\
6\end{array}$ & $\begin{array}{l}<8 \\
<8 \\
<8 \\
<8 \\
<8 \\
<8\end{array}$ & $\begin{array}{l}<8 \\
<8 \\
<8 \\
<8 \\
<8 \\
<8\end{array}$ & $\begin{array}{l}<8 \\
<8 \\
<8 \\
<8 \\
<8 \\
16\end{array}$ & $\begin{array}{r}<8 \\
<8 \\
8 \\
<8 \\
8 \\
256\end{array}$ & $\begin{array}{l}<8 \\
<8 \\
<8 \\
<8 \\
<8 \\
16\end{array}$ & $\begin{array}{l}<8 \\
<8 \\
<8 \\
<8 \\
<8 \\
32\end{array}$ & $\begin{array}{r}<8 \\
<8 \\
32 \\
16 \\
32 \\
1024\end{array}$ & $\begin{array}{r}<8 \\
<8 \\
32 \\
32 \\
64 \\
2048\end{array}$ & $\begin{array}{r}<8 \\
<8 \\
64 \\
64 \\
128 \\
1024\end{array}$ & $\begin{array}{r}16 \\
8 \\
128 \\
128 \\
256 \\
2048\end{array}$ & $\begin{array}{r}32 \\
8 \\
64 \\
128 \\
256 \\
1024\end{array}$ & $\begin{array}{r}128 \\
8 \\
256 \\
512 \\
256 \\
512\end{array}$ & $\begin{array}{r}<8 \\
8 \\
128 \\
64 \\
256 \\
2048\end{array}$ & $\begin{array}{r}16 \\
16 \\
128 \\
128 \\
256 \\
2048\end{array}$ & $\begin{array}{r}16 \\
8 \\
64 \\
128 \\
128 \\
1024\end{array}$ & $\begin{array}{r}16 \\
8 \\
32 \\
128 \\
128 \\
512\end{array}$ \\
\hline
\end{tabular}

Table I Influence of increasing esterification and of an increasing amount of esterified polysaccharide on the titre value

${ }^{1}$ On the basis of preceding titrations it was expected that there would be two sera with low, two with intermediate, and two with high titres. 'Per $\mathrm{ml}$ red cell suspension. 
six sera. On the basis of preceding titrations it had been established that two of these sera had low titres, two moderately raised, and two high titres. Of each ester, $2 \cdot 5,5,10$, and $20 \mu \mathrm{g}$ per ml erythrocytes was used for sensitization (table I). Esterification with 2.5 or $5 \mathrm{mg}$ myristoylchloride gave low titres with all sera, as in these cases the ester group content of the antigen was insufficient to sensitize the erythrocytes. The results obtained with polysaccharide esterified with 7.5 and $10 \mathrm{mg}$ myristoylchloride show little difference. In further experiments the polysaccharide esterified with $10 \mathrm{mg}$ myristoylchloride was used. When increasing amounts of ester were used for sensitization of erythrocytes the differences between high and low titres decreased and the reading of the endpoints was more difficult at the 10 and $20 \mu \mathrm{g} / \mathrm{ml}$ level. With the preparation used, $2 \cdot 5$ and $5 \mu \mathrm{g}$ per $\mathrm{ml}$ erythrocytes gave satisfactory results. In subsequent experiments $2 \cdot 5 \mu \mathrm{g}$ ester was used for the sensitization of erythrocytes.

\section{THE SPECIFICITY OF THE REACTION}

The specificity of the agglutination reaction was investigated by examining the behaviour of esterified A-CHO with homologous and heterologous antisera and by absorption experiments.

Anti-A, anti-Avariant, anti-C, and anti-G rabbit serum was tested with sensitized erythrocytes (table II). A high titre was only observed with the homologous and not with the heterologous sera.

Anti-A rabbit serum with a titre of 4096 was absorbed with increasing amounts of A-CHO (table III). It appeared that the ASPAT was completely abolished after absorption of the serum with 1000 $\mu \mathrm{g} / \mathrm{ml}$ A-CHO.

\begin{tabular}{llr}
\hline Antigen & Serum & Titre \\
\hline A polysaccharide & Anti A & 1024 \\
A polysaccharide & Anti Avartant & $<4$ \\
A polysaccharide & Anti C & $<4$ \\
A polysaccharide & Anti G & $<4$ \\
\hline
\end{tabular}

Table II Anti-A haemagglutination titre with homologous and heterologous rabbit antisera

\begin{tabular}{lr}
\hline Anti-A Rabbit Serum & Titre \\
\hline Unabsorbed & 4096 \\
Absorbed with $125 \mu \mathrm{g}$ polysaccharide & 1024 \\
Absorbed with $250 \mu \mathrm{g}$ polysaccharide & 256 \\
Absorbed with $500 \mu \mathrm{g}$ polysaccharide & 64 \\
Absorbed with $1000 \mu \mathrm{g}$ polysaccharide & $<4$
\end{tabular}

Table III Effect of absorption of anti-A rabbit serum with group A polysaccharide on the ASPAT
Anti-A rabbit serum with a titre of 512 was absorbed with $62.5 \mu \mathrm{g}$ of A, Avariant, C, G, and F polysaccharide (table IV). With A-CHO all antibodies could be absorbed from this serum. Absorption with the other polysaccharides had no signifi. cant effect on the ASPAT.

\begin{tabular}{ll}
\hline Anti-A Rabbit Serum & Titre \\
\hline Unabsorbed & 512 \\
Absorbed with A polysaccharide & $<4$ \\
Absorbed with Avariant polysaccharide & 256 \\
Absorbed with C polysaccharide & 256 \\
Absorbed with F polysaccharide & 512 \\
Absorged with G polysaccharide & 256 \\
\hline
\end{tabular}

Table IV Effect of absorption of anti-A rabbit serum with $62.5 \mu g$ group $A, A$ variant, $C, F$, and $G$ streptococcal polysaccharide

Sera of three patients with infection caused by group A streptococci were absorbed with A-CHO (table V). With $125 \mu \mathrm{g} \mathrm{A-CHO}$ all antibodies were completely absorbed from these sera. After absorption with $62.5 \mu \mathrm{g}$ two sera showed no residual titre whereas the titre of the third serum decreased significantly from 1024 to 128 .

\begin{tabular}{llll}
\hline Serum & Unabsorbed & \multicolumn{3}{l}{ Absorbed with } \\
\cline { 3 - 4 } & & $125 \mu \mathrm{A}$ A-CHO & $62.5 \mu \mathrm{A}-\mathrm{CHO}$ \\
\hline 1 & 512 & $<8$ & $<8$ \\
2 & 256 & $<8$ & $<8$ \\
3 & 1024 & $<8$ & 128 \\
\hline
\end{tabular}

Table V Effect of absorption of human sera with group $A$ polysaccharide on the ASPAT

\section{ASPAT, ASO, AND ANTI-DNASE B TITRES IN STREPTOCOCCAL INFECTIONS}

The titres of the three reactions were estimated in a group of 52 children with proved streptococcal infection and in 52 age- and season-matched controls. Streptococcal infection was defined as follows: isolation of group A streptococcus, clinical symptoms compatible with streptococcal infection, eg, tonsillitis, enlarged cervical lymph nodes, and one or more of the following signs: ESR $\geqslant 20 \mathrm{~mm}$, leucocytosis $\geqslant 20.000$, fever $\geqslant 38^{\circ} \mathrm{C}$. When the group $A$ streptococcus was isolated from pus or a septic wound it was assumed that the disorder was caused by this organism. Each serum represents one patient. The mean time period between the beginning of the infection and the acquisition of the serum amounted to three weeks. The controls consisted of a group of 


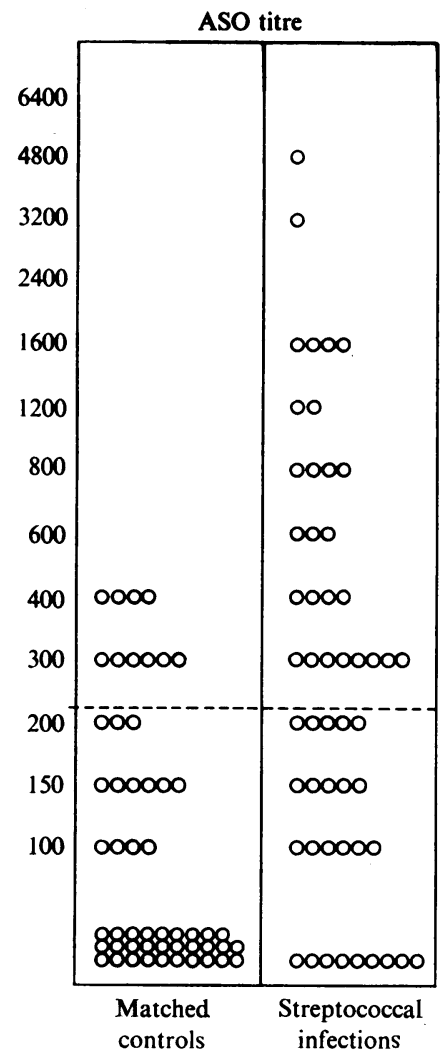

(52)

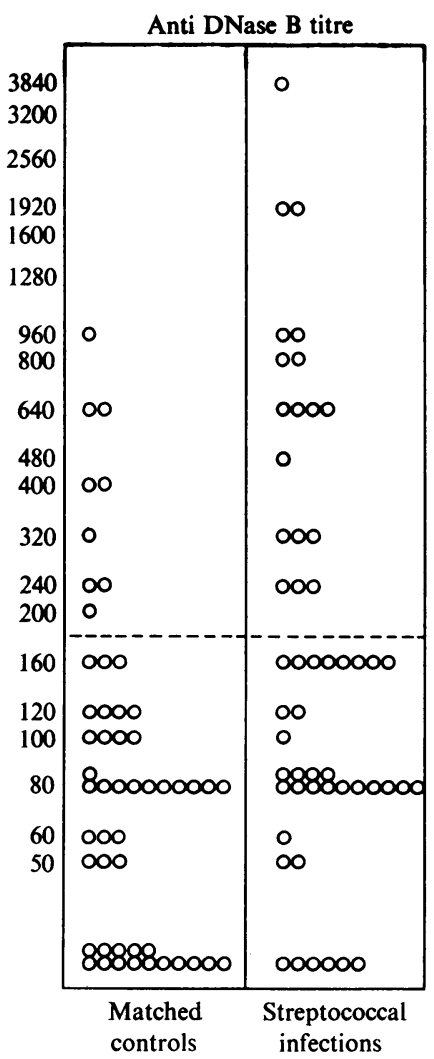

(52)

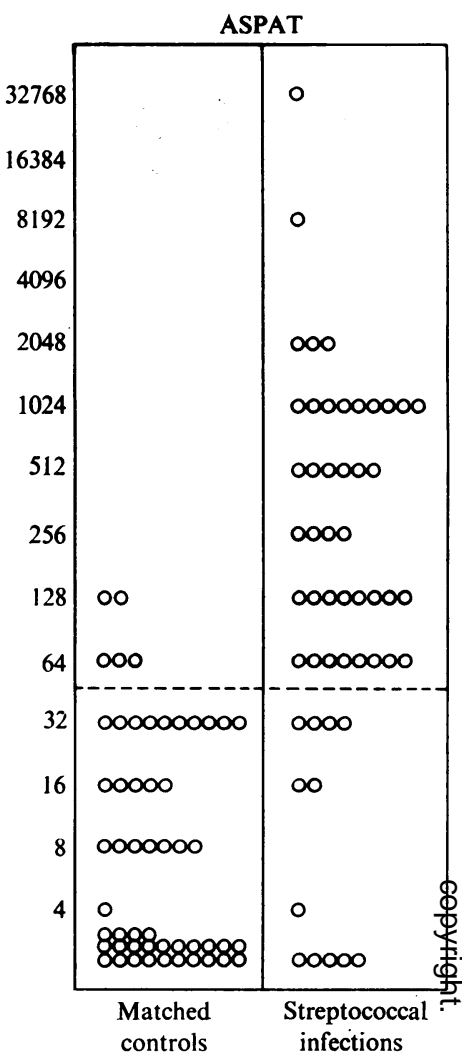

(52)

(52)

Fig Scattergrams comparing the ASO and anti-DNase-B titres and the ASPAT in children with proved streptococcal infections and in age- and season-matched controls.

children without symptoms or recent history of streptococcal infection.

It can be seen in the figure that both the ASO and the anti-Dnase B titres and the ASPAT are higher in streptococcal infections than in the controls. The $\log$ titres were shown to follow a normal distribution to a sufficient approximation in both groups for each of the three titration methods. Consequently the geometric mean titres were estimated according to the method of maximum likelihood for random samples from log normal populations with onesided censoring of type I. The results obtained are shown in table VI. In each case the values found in the group of children with infection are significantly higher than in the controls. There is clearly less overlap between the controls and the group with streptococcal infections in the ASPAT than in the ASO and anti-DNase B titres. Arbitrarily the limit between normal and elevated titres was set at a level which was not exceeded by $80 \%$ of the controls. According to this rule the normal values found in children were

\begin{tabular}{lllr}
\hline Titre & Controls & Streptococcal Infection & \multicolumn{1}{l}{$\mathbf{P}^{1}$} \\
\hline ASO & 90 & 270 & 0.0003 \\
Anti DNase B & 81 & 161 & 0.0007 \\
Anti A-CHO & 5.4 & 144 & $\ll 0.0001$ \\
\hline
\end{tabular}

Table VI Geometric mean titres from censored data $(n=52)$

${ }^{1}$ Statistical significance of differences was tested according to the sign test for paired data ( $P$ values, two sided).

the following: ASO titre 200, anti-DNase B titre 160, and ASPAT 32. Table VII shows how often an elevated titre can be demonstrated when the three reactions are used either separately or in combina- N tion in children with streptococcal infections and in $\widetilde{O}$ controls. In the group with streptococcal infection

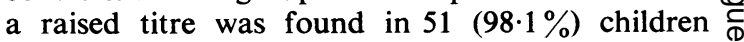
against $17(32.7 \%)$ in the controls $\left(\chi^{2}=46 \cdot 2\right.$; $\mathbf{P}<0.001)$. In the patients the total score for the 0 elevation of ASO titres amounted to $27(51.9 \%)$, of 웅 anti-DNase B titres to $18(34.6 \%)$, and of ASPAT 


\begin{tabular}{lll}
\hline Titre & Controls & Patients \\
\hline ASO & 5 & 5 \\
ASO + anti DNase B & 3 & 6 \\
ASO + anti A-CHO & 0 & 8 \\
ASO + anti DNase B + anti A-CHO & $2(10)^{1}$ & $8(27)^{1}$ \\
Anti DNase B & 4 & 0 \\
Anti DNase B + anti A-CHO & $0(9)^{2}$ & $4(18)^{2}$ \\
Anti A-CHO & $3(5)^{3}$ & $20(40)^{3}$ \\
Negative & 35 & 1 \\
& 52 & 52 \\
\hline
\end{tabular}

Table VII Elevated titres in sera of children with proved streptococcal infection and in sera of age- and season-matched controls

${ }^{1}$ Total score ASO titre.

${ }^{2}$ Total score anti DNase B titre.

${ }^{3}$ Total score ASPAT.

to $40(76.9 \%)$. From this it follows that the contribution of the ASPAT to the diagnosis of streptococcal infection in children might be greater than that of both other reactions.

Kaplan, Top, Dudding, and Wannamaker (1971) tried to distinguish active infection with group A streptococci from the carrier state in the symptomatic child. True infection was defined as the recovery of the organism followed by a subsequent rise in antibody level. In 34 children from our series sera were obtained during the active stage and two to six weeks after the initial bleeding. A significant antibody response was defined as a rise in titre of two dilution increments or more. In table VIII the figures of Kaplan et al (1974) are compared with the results of the present study. When only the ASO and anti-DNase $B$ reactions were performed a significant rise in antibody titre was found in $44 \%$ of children in our study in one or both reactions. This percentage is equivalent to Kaplan's. The ASPAT alone showed a rise of two dilution increments or more in both studies of $42 \%$ and $25 \%$ respectively. When the results of the ASPAT, ASO, and anti-DNase B reactions are combined these percentages were $68 \%$ and $54 \%$ respectively. An increase in positive scores in 15 patients when two reactions are performed to 23 patients with three reactions as found in the present series is on the borderline of significance $\left(\chi^{2}=2.9 ; 0.05<P<0.1\right)$.

\section{Discussion}

A specific and sensitive serological test for the demonstration of streptococcal infection in the listless child with fever or subfebrile temperature may be an useful adjunct to the diagnostic outfit of the paediatrician. This also applies to cases in which the diagnosis of rheumatic fever or acute glomerulonephritis is considered.

The ASPAT reaction described here appears to be specific for the demonstration of antibodies to the group-specific polysaccharide of group A streptococci. In infections by group A streptococci elevations of the ASPAT were observed more frequently than of antibody titres to streptolysin $O$ and DNase B. This can possibly be explained by the fact that the children with streptococcal infections described above were treated, with a few exceptions, with antibiotics from the first day of illness. As a consequence the streptococci were killed which results in antigenic stimulation of short duration by extracellular products and probably of longer duration by cellular components of the streptococcus.

It is stated by Kaplan et al (1974) that to establish the existence of streptococcal infection a rise of at least two dilution increments between the acute and convalescent sera is required. If this criterion is accepted the positive score obtained by the combined titres against streptolysin $\mathrm{O}$ and DNase-B was enhanced in the present series from 44 to $68 \%$. This is an increase of just over $50 \%$.

Raised antibody levels against A-CHO returned to normal in a period of five months in almost all children. In a few cases titres did not decrease and

\begin{tabular}{llll}
\hline Antibody Response of & \multicolumn{2}{l}{ Present Study } & Kaplan et al \\
\cline { 2 - 3 } & No. of Patients & Percentage & Percentage \\
\hline ASO & 10 & $29 \cdot 5$ & 37 \\
Anti DNase B & 10 & $29 \cdot 5$ & 27 \\
Anti A-CHO & 14 & 42 & 252 \\
ASO and/or anti DNase B & 15 & 44 & 44 \\
ASO and/or anti A-CHO & 20 & 59 & 36 \\
Anti DNase and/or anti A-CHO & 18 & 53 & 54 \\
ASO and/or anti DNase B and/or anti A-CHO & 23 & 68 & 46 \\
No rise in antibody titre & 11 & 32 & \\
\hline
\end{tabular}

Table VIII Antibody response in patients with symptoms compatible with the diagnosis of streptococcal infection in which group A streptococci were isolated

${ }^{1}$ Positive antibody response is a rise in titre of $\geqslant 2$ dilution increments between the acute and the reconvalescent phase. ${ }^{2}$ Radioimmune precipitation. 
remained at the same level for many months without apparent reason. All children had a history of recently acquired streptococcal infections at the time of the bleeding. These histories as well as the relatively rapid decrease of the antibody titres point to the fact that in the ASPAT antibodies are measured which have been formed recently against A-CHO. Persistence of high titres may be ascribed to the existence of chronic infection or to the presence of cross-reacting antibodies as described by Dudding and Ayoub (1968) in patients with valvular lesions after rheumatic fever. Children with a history of rheumatic fever or with rehumatic valvular disease were not, however, found in the present series.

We wish to thank Dr W. R. Maxted, Central Public Health Laboratory, Colindale, London, for providing some of the rabbit antisera. Statistical evaluation of some of the results was performed by $\mathrm{Mr} R$. van Strik, Department of Biostatistica, Erasmus University, Rotterdam. The project was supported in part by Praeventie Fonds, the Hague.

\section{References}

Dudding, B. A., and Ayoub, E. M. (1968). Persistence of streptococcal group $A$ antibody in patients with rheumatic valvular disease J. exp. Med., 128, 1081-1098.

Erwa, H. H., Maxted, W. R., and Brighton, W. D. (1969). A latex agglutination test for the measurement of antibodies to groupspecific streptococcal polysaccharides. Clin. exp. Immunol., 4, 311-321.

Fuller, A. T. (1938). The formamide method for the extraction of polysaccharides from haemolytic streptococci. Brit. J. exp. Path., 19, 138-139.
Goldstein, I., and Caravanno, R. (1967). Determination of anti group A streptococcal polysaccharide antibodies in human sera by an hemagglutination technique. Proc. Soc. exp. Biol. (N.Y.), 124, 1209-1212.

Hämmerling, U., and Westphal, O. (1967). Synthesis and use of O-stearoyl polysaccharides in passive hemagglutination and hemolysis. Europ. J. Biochem., 1, 46-50.

Kaplan, E. L., Ferrieri, P., and Wannamaker, L. W. (1974). Comparison of the antibody response to streptococcal cellular and extracellular antigens in acute pharyngitis. J. Pediat., 84, 21-28.

Kaplan, E. L., Top, F. H., Jr., Dudding, B. A., and Wannamaker, L. W. (1971). Diagnosis of streptococcal pharyngitis: Differentiation of active infection from the carrier state in the symptomatic child. J. infect. Dis., 123, 490-501.

Karakawa, W. W., Osterland, C. K., and Krause, R. M. (1965). Detection of streptococcal group-specific antibodies in human sera. J. exp. Med., 122, 195-205.

Klein, G. C., Baker, C. N., Addison, B. V., and Moody, M. D. (1969). Microtest for streptococcal antideoxyribonuclease B. Appl. Microbiol., 18, 204-206.

McCarty, M., and Lancefield, R. C. (1955). Variation in the groupspecific carbohydrate of group A streptococci I. Immunochemical studies on the carbohydrates of variant strains. J. exp. Med., 102, 11-28.

Marker, S. C., and Gray, E. D. (1972). Simple method for the preparation of streptococcal nucleases. Appl. Microbiol., 23, 368371 .

Michel, M. F., and Krause, R. M. (1967). Immunochemical studies on the group and type antigens of group F streptococci and the identification of a group-like carbohydrate in a type II strain with an undesignated group antigen. J. exp. Med., 125, 10751089.

Pavlovskis, O., and Slade, H. D. (1969). Absorption of 3H-fatty acid esters of streptococcal groups A and E cell wall polysaccharide antigens by red blood cells and their effect on hemagglutination. J. Bact., 100, 641-646.

Rantz, L. A., and Randall, E. A. (1945). A modification of the tecto nic for determination of the anti-streptolysin titer. Proc. So $\perp$ exp. Biol. (N.Y.), 59, 22-25.

Schmidt, W. C., and Moore, D. J. (1965). The determination of antibody to group A streptococcal polysaccharide in human sera bP hemagglutination. J. exp. Med., 121, 793-806.

Slade, H. D., and Hämmerling, U. (1968). Detection by hemagglutination of antibodies to group $A$ and group $E$ streptococci by the use of O-stearoylderivatives of their cell wall carbohydrategrouping antigens. J. Bact., 95, 1572-1579. 